(4.2 vs 3.4 with milk substitute) especially because of an increased weight of perirenal adipose tissue $(245 \mathrm{~g}$ vs $174 \mathrm{~g})$. Castration of kids increased the fattening score of their carcasses (4.31 vs 3.94 for intact kids) and the weight of adipose tissues (mesenteric fat $346 \mathrm{~g}$ vs $296 \mathrm{~g}$, perirenal fat $352 \mathrm{~g}$ vs $341 \mathrm{~g}$ ) except omental tissue.

Increase in live weight at slaughter was the most efficient factor to improve fattening of kid carcasses. Goat milk and castration could also be used to improve fattening of kids, but castration markedly reduced growth rate (ADG $228 \mathrm{~g} / \mathrm{d}$ vs $272 \mathrm{~g} / \mathrm{d}$ for intact kids). Increasing the fat content of milk substitute had a slightly favourable effect, appearing relatively late in omental and perirenal tissue.

Key words : Kid fattening, kid carcass, milk substitute, castration, goat milk, weight at slaughter.

\title{
The effect of suckling type on the pre-and postweaning lactation performance of Damascus goats and the growth rate of the kids
}

\author{
M. HADJIPANAYIOTOU \\ Agricultural Research Institute, Nicosia, Cyprus
}

Fourty-nine goats were randomly allocated at 2 days post-kiclding to double (DS), single (SS) and no-suckling (OS) treatments. Artificially reared kids were given either ewemilk (Provilamb : 25.8 p. 100 fat, 24.2 p. 100 protein) or calfmilk (Provifok: 15 p. 100 fat, 22.5 p. 100 protein) replacer. The ewe and calfmilk replacers were reconstituted in the ratio of 1 part powder to 5 or 4 parts of water, respectively.

Separation of kids from their dams reduced milk yield to weaning (DS 182, SS 179, OS $121 \mathrm{~kg} /$ goat) and from weaning (56 days postkidding) to 90 days post-partum (DS 102 , SS 90 , OS $72 \mathrm{~kg} /$ goat). There was no significant difference in milk yield between DS and SS goats. Milk sold till weaning was significantly more abundant in OS and SS goats (DS 63, SS 109 , OS $121 \mathrm{~kg} /$ goat). Milk sold from weaning to 90 days was similar in SS and DS goats, but lower in OS ones. Live weight changes between goats were not significant (DS 0.044 ; SS 0.09 ; OS $0.023 \mathrm{~kg} /$ goat/day). DS goats consumed more concentrate mixture than SS or OS ones (DS 2.13 , SS 2.08 , OS $1.85 \mathrm{~kg} /$ goat/day).

Suckling kids reared with their dams as singles were heavier at weaning $(14.6 \mathrm{~kg})$ than twins $(12.7 \mathrm{~kg})$. They were also heavier than kids born as single or twins and reared artificially in a kid-bar on calf milk replacer $(12.7 \mathrm{~kg})$. Twin suckled kids, however, were not significantly heavier than those reared artificially in a kid-bar on cow or ewemilk replacer $(13.4 \mathrm{~kg})$, although 4 kids reared on calf milk replacer died during the rearing period and their data were cxcluded from the analysis. Differences between kids reared artificially on ewemilk replacer and single suckled kids were not significant.

It may be concluded that SS of goats did not reduce milk yieid compared to DS : SS increased marketable milk and artificially reared kids grew satisfactorily.

Key words : Suckling type, goat, milk, artificial rearing, kids. 